\title{
Production of Smokeless Briquette Charcoals from Wet Cake Waste of Ethanol Industry
}

\author{
Walairat Uttamaprakrom ${ }^{1, *}$ and Tharapong Vitidsant ${ }^{2}$ \\ 1 Energy Research Institute, Floor 12 Building 3, Phayathai Rd, Pathumwan, Bangkok 10330, Thailand \\ 2 Department of Chemical Technology, Faculty of Science, Chulalongkorn University, Phayathai Rd, \\ Pathumwan, Bangkok 10330, Thailand \\ E-mail: walairat@eri.chula.ac.th ${ }^{1, *}$, tharapong.v@chula.ac.th²
}

\begin{abstract}
The main aim of this research was to improve physical property of wet cake waste from ethanol industry to produce smokeless briquette charcoals as alternative fuels. By carbonization at $400,450,500$ and $550^{\circ} \mathrm{c}$ vary times $30,45,60$ and 90 minutes in oxygen-limited conditions. The maximum yields and fixed carbon were obtained at temperature $500^{\circ} \mathrm{C}, 60$ minutes. This condition has $40.50 \%$ yields, $1.17 \%$ moisture, $34.42 \%$ ash, $16.57 \%$ volatile matter and $47.84 \%$ fixed carbon. Then bring wet cake waste to briquette charcoals in two types such as hot and cold compressed.After carbonization hot and cold compressed have higher heating value 20,257.25 and 24,790.21 KJ/kg respectively. In addition cost-benefit and cost-effectiveness analysis, hot compressed cost $0.17 \mathrm{baht} /$ piece, total production at breakeven 704,225 pieces and payback period of 0.18 years, while cold compressed cost $0.3175 \mathrm{baht} /$ piece, total production at breakeven 341,297 pieces and payback period of 0.17 years.
\end{abstract}

Keywords: Ethanol industry, wet cake waste, carbonization, smokeless briquette charcoals, hot compressed, cold compressed.

ENGINEERING JOURNAL Volume 16 Issue 2

Received 11 August 2011

Accepted 29 November 2011

Published 1 April 2012

Online at http://www.engj.org

DOI:10.4186/ej.2012.16.2.5 


\section{Introduction}

Ethanol industry in Thailand has significantly expanded because the government policy to encourage and advocate in terms of the national energy security. This can be seen from the development of renewable energy "Gasohol development plan for 15 years (2008-2022)", which focuses on the energy research by utilization the energy crops such as sugarcane, cassava and sweet sorghum to blend in gasoline replacing Methyl Tertiary Butyl Ether (MTBE) from aboard and also caused environmental pollution as shown in Table 1 [1].

Table 1. Potential and targets of ethanol plan (the development of renewable energy plan for 15 years) [1].

\begin{tabular}{lcccc}
\hline $\begin{array}{l}\text { Types of } \\
\text { energy }\end{array}$ & $\begin{array}{c}\text { The potential } \\
\text { (Million litres/day) }\end{array}$ & $\begin{array}{c}\text { 2008-2011 } \\
\text { (Million litres/day) }\end{array}$ & $\begin{array}{c}\text { 2012-2016 } \\
\text { (Million litres/day) }\end{array}$ & $\begin{array}{c}\text { 2017-2022 } \\
\text { (Million litres/day) }\end{array}$ \\
\cline { 1 - 3 } Ethanol & 3.0 & 3.0 & 6.2 & 9.0 \\
\hline
\end{tabular}

From gasohol development plan resulted in the production of ethanol continuously increased (20082011) as seen from the amount of ethanol production as shown in Fig. 1 [1].

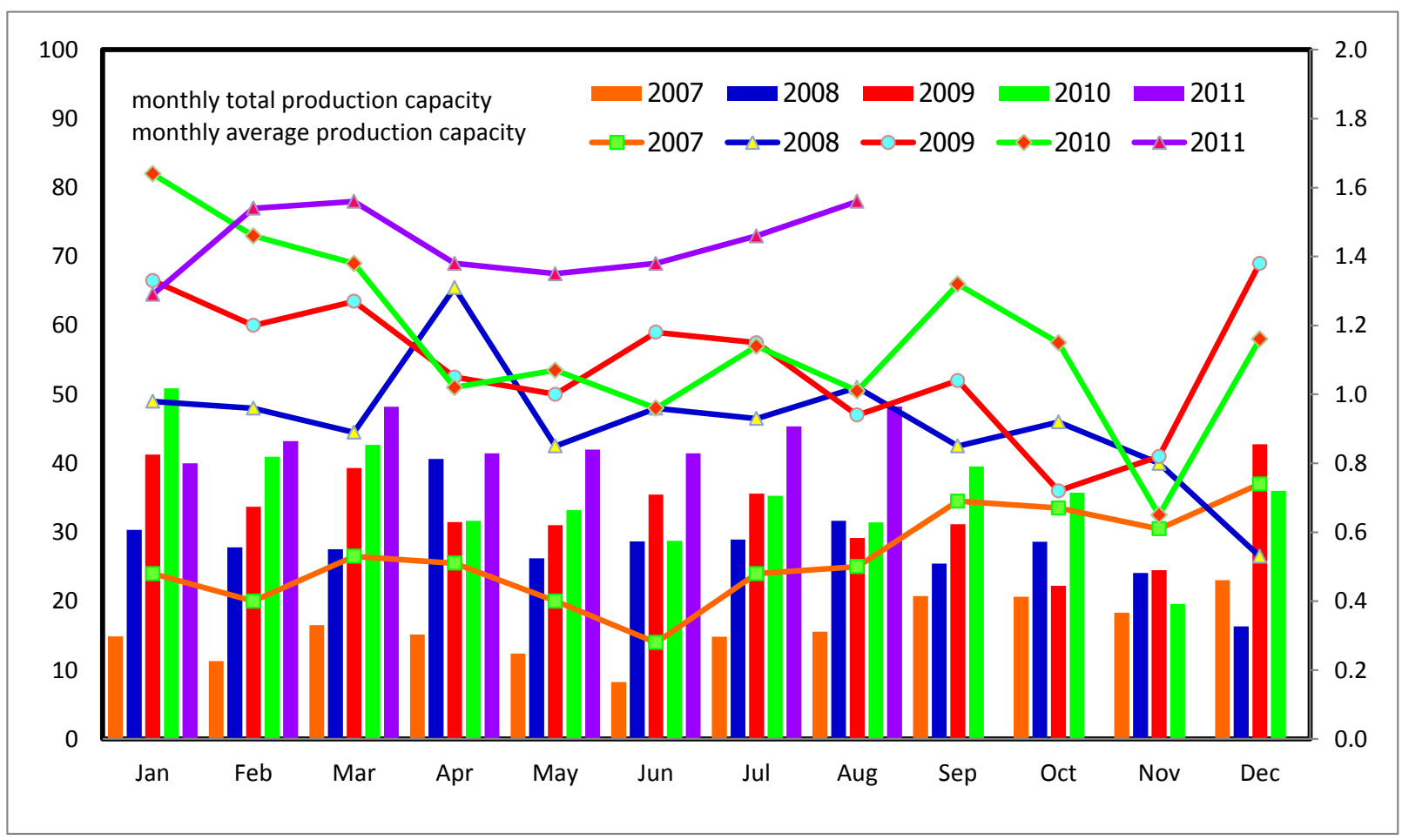

Fig. 1. Production of ethanol as fuel [1].

Recently data showed that there are a number of operators allowed construction of ethanol plants for fuel total 47 as shown in Table 2. Ethanol plants that operation today, there were 19 and total production capacity 2,925,000 Litres/day as shown in Table 3. Ethanol plants are expected to be completed in late 2011were 6 and total production capacity 2,420,000 Litres/day as shown in Table 4 [1]. 
Table 2. Operators are allowed construction ethanol plants for fuel [1].

\begin{tabular}{lcr}
\hline Type of material & Number of factories & Total Capacity (Litres/day) \\
\hline Cane & 1 & 200,000 \\
Cassava & 27 & $8,290,000$ \\
Molasses & 5 & 675,000 \\
Sugarcane/Molasses & 12 & $1,810,000$ \\
Cassava/Molasses & 5 & 770,000 \\
Sugarcane/Cassava & 1 & 200,000 \\
Molasses/Cassava/Sugarcane & 2 & 250,000 \\
Pulp cassava & 1 & 100,000 \\
Total production capacity & & $\mathbf{1 2 , 2 9 5 , 0 0 0}$ \\
\hline
\end{tabular}

Table 3. Ethanol operation plants [1].

\begin{tabular}{lcr}
\hline Type of material & Number of factories & Total Capacity (Litres/day) \\
\hline Molasses & 13 & $1,865,000$ \\
Sugar cane/Molasses & 2 & 280,000 \\
Cassava & 3 & 500,000 \\
Molasses/Cassava & 1 & 200,000 \\
Total production capacity & & $\mathbf{2 , 9 2 5 , 0 0 0}$ \\
\hline
\end{tabular}

Table 4. Ethanol plants are expected to be completed in late 2011 [1].

\begin{tabular}{lcr}
\hline Type of material & Number of factories & Total Capacity (Litres/day) \\
\hline Molasses & 1 & 600,000 \\
Chipped cassava & 5 & $1,820,000$ \\
Total production capacity & & $\mathbf{2 , 4 2 0 , 0 0 0}$ \\
\hline
\end{tabular}

Ethanol industry in Thailand uses mainly agricultural raw materials from molasses and cassava. Data from the survey, the amount of waste from ethanol production from molasses and cassava details as following Table 5 .

Table 5. Products and By-products from Ethanol Industry 150,000 litres/day [2].

\begin{tabular}{lcc}
\hline & Ethanol Industry 150,000 litres/day & \\
\hline Input & Molasses & Chipped cassava \\
$\mathrm{Raw}$ & $350-370$ & $540-550$ \\
$\mathrm{H}_{2} \mathrm{O}\left(\mathrm{m}^{3} /\right.$ day) & $1,200-1,500$ & $1,000-1,300$ \\
Yeast powder (kg/day) & $20-80$ & $20-80$ \\
Enzyme (kg/day) & $20-800$ & - \\
Other chemicals (kg/day) & $1,000-5,000$ & $1,000-5,000$ \\
\hline Output & Molasses & Chipped cassava \\
ethanol (litres/day) & 150,000 & 150,000 \\
$\mathrm{CO}_{2}$ (tons/day) & $100-120$ & $100-120$ \\
Fusel Oil (Litres/day) & $300-600$ & $300-600$ \\
Wet cake (tons/day) & - & $\mathbf{1 0 0 - 2 0 0}$ \\
Wastewater (m $/$ day) & $1,200-1,400$ & $1,000-1,300$ \\
\hline
\end{tabular}


From table 5. Many by-products from molasses and cassava 150,000 litres/day were similar in each step such as $\mathrm{CO}_{2}$ generated during ermentation. Fusel oil by distillation. Wet cake waste from water refining and separation including waste water. Currently waste from the ethanol production process haven't been managed and utilized as they should [1].

Carbonization process is based on thermal treatment at high temperature under a controlled atmosphere.The main steps are as follow: moisture removal,volatile compounds evaporation,biomass transformation and charcoal purification. In addition carbonization process has been proven to be an effective method to increase fixed carbon and heating value. In the literature, several studies have been reported on the carbonization of different biomass sources. [3] Studied lucent, oak wood, corn cobs and nut shells by rapid carbonization at pressure 1 megapascal in fixed bed reactor, showed that the proportion of char is 29.5 to $40 \%$ of dry weight $59-63 \%$ of the carbon in the biomass is converted to carbon in the char and energy efficiency was 55.1 to 66.3\%.[4] Studied the carbonization of three types of biomass such as eucalyptus wood, bagasse and coconut palms at low temperatures $\left(400-450^{\circ} \mathrm{C}\right)$ showed that when the temperature rises percent by weight of carbon is increased. At $450^{\circ} \mathrm{C}$ is the highest percentage by weight of carbon in three types biomass. [5] Studied sugar-cane bagasse fly ash (SCBFA) which contains a high volume (>30\% by weight) of charcoal to briquette by hand pressed mixed with a binder (starch). Thermogravimetric analysis (TGA) and differential scanning calorimetry (DSC) were used to characterize the ashes and the briquettes. The results show that sugar-cane bagasse fly ash (SCBFA) can be used to produce briquettes with an average density of $1.12 \mathrm{gcm}^{3}$ and calorific value of $25,551 \mathrm{~kJ} / \mathrm{kg}$. [6] The gases and chars produced during fast pyrolysis of maize stalk, rice straw, cotton straw and rice husk at temperatures ranging from 600 to $1000^{\circ} \mathrm{C}$ found that gas yield increased by more than $80 \%$ from 600 to $1000^{\circ} \mathrm{C}$ while the char and liquid yield decreased.

If calculated the amount of wet cake that occurs during 1 year, average 150 tons/day, thus total volume of wet cake 45,000 tons/year, charcoal production up to 200 million pieces/year. From table 5 if five ethanol plants from cassava full operated in late 2011 at production capacity 1,820,000 liters/day as a result total volume of wet cake 400,000 tons/year which able to produce briquette charcoals up to 1,700 million pieces/year. In this paper, we study the wet cake waste due to a large amount of per day, difficult to handle and impact on the environment for long term. By improving the physical property prior to use into hot and cold briquette charcoals for proper utilization including study the economics for commercial production.

\section{Equipment and Experimental}

\subsection{Tools and Equipment}

1. Screwdryer capacity $100 \mathrm{~kg} / \mathrm{hr}$

2. Tubular furnace CARBOLITE MODEL CTF $12 / 75 / 700 / 201$

3. Incubators MMM MODEL ECOCELL

4. MODEL SC96 AVM MODUTEMP

5. Bomb calorimeter PARR MODEL 6200

6. Tube furnace : type $21100\left(0-1,200^{\circ} \mathrm{C}\right)$ Thermolyne Corporation, USA

7. CHN Elemental Analyzer LEGO CHN-2000

8. Rapid test soil kit NPK

\subsection{Experimental Setup}

In this research investigation, wet cake waste from water refining and separation from ethanol production from chipped cassava. Wet cake waste is low quality because low fixed carbon and heating value. The process flow diagram of carbonization process is shown in Figs. 2 and 3. The process incorporates tubular furnace for insert sample, heat control and nitrogen gas tank to flow gas into reactor. 


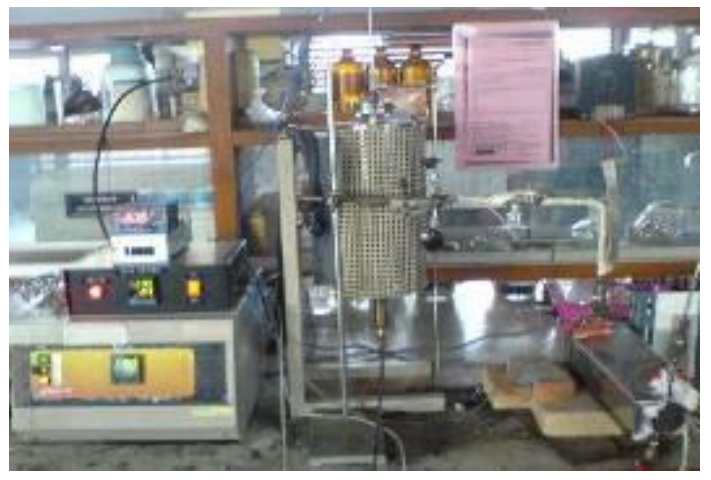

Fig. 2. The carbonization device.

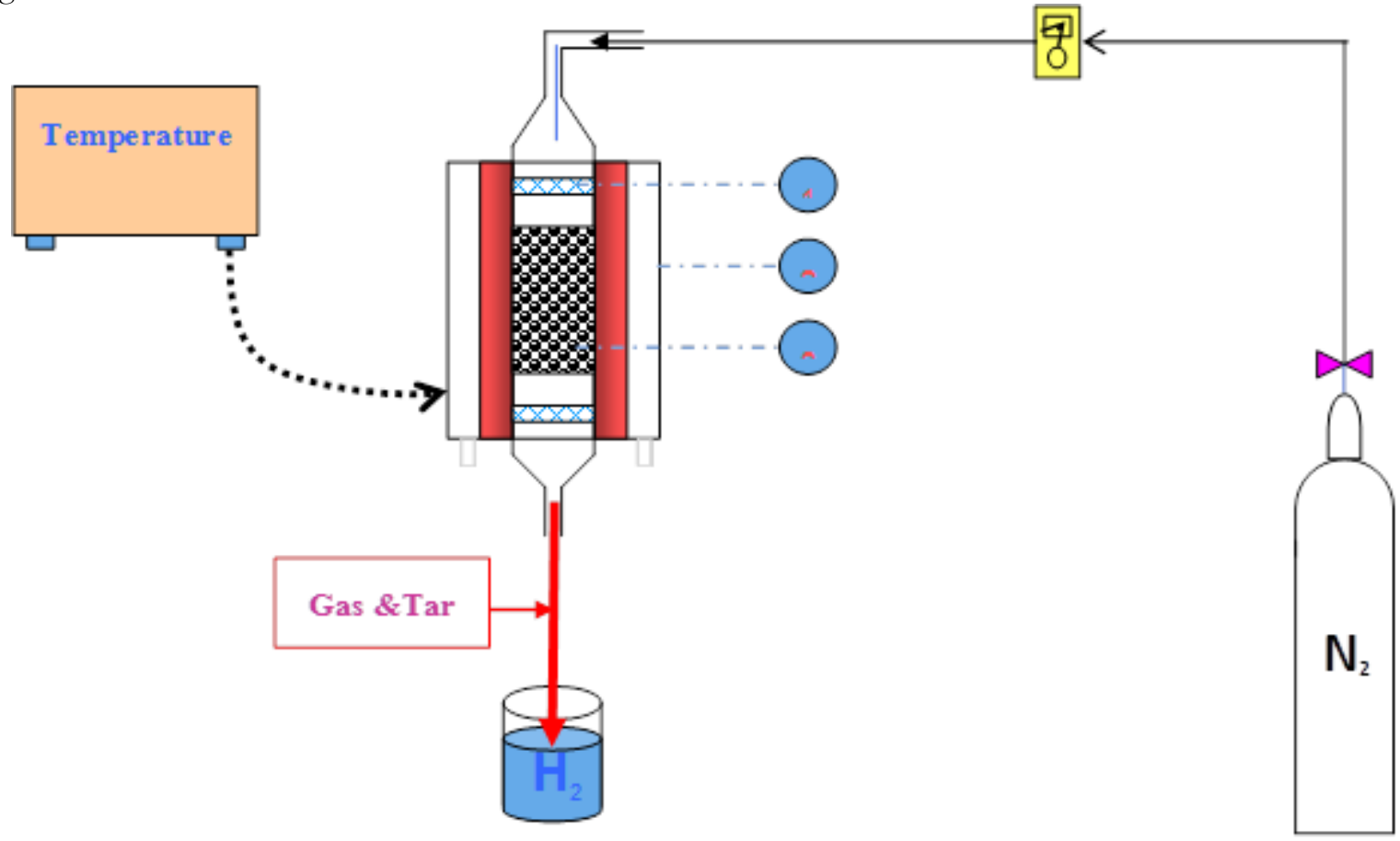

Fig. 3. The process diagram of Carbonization.

\subsection{Experimental Methods}

Drying wet cake by screwdry production capacity $100 \mathrm{~kg} / \mathrm{hr}$. To rest about $10 \%$ moisture (moisture in the wet cake, approximately 40\%). Then bring wet cake crushed to the size 1.18 to $2.36 \mathrm{~mm}$.

The carbonization process were operated at different temperature $\left(400,450,500\right.$ and $\left.550^{\circ} \mathrm{C}\right)$ and time (30, 45, 60 and 90 minutes) in oxygen-limited. To investigate the effect of temperature and time on fixed carbon volume, heating value and \%yield by letting the $\mathrm{N} 2$ gas flow rate $50 \mathrm{ml} / \mathrm{min}$. After knowing the optimal carbonization conditions then bring wet cake to briquette in two types: hot and cold compressed. Details are as follows: 

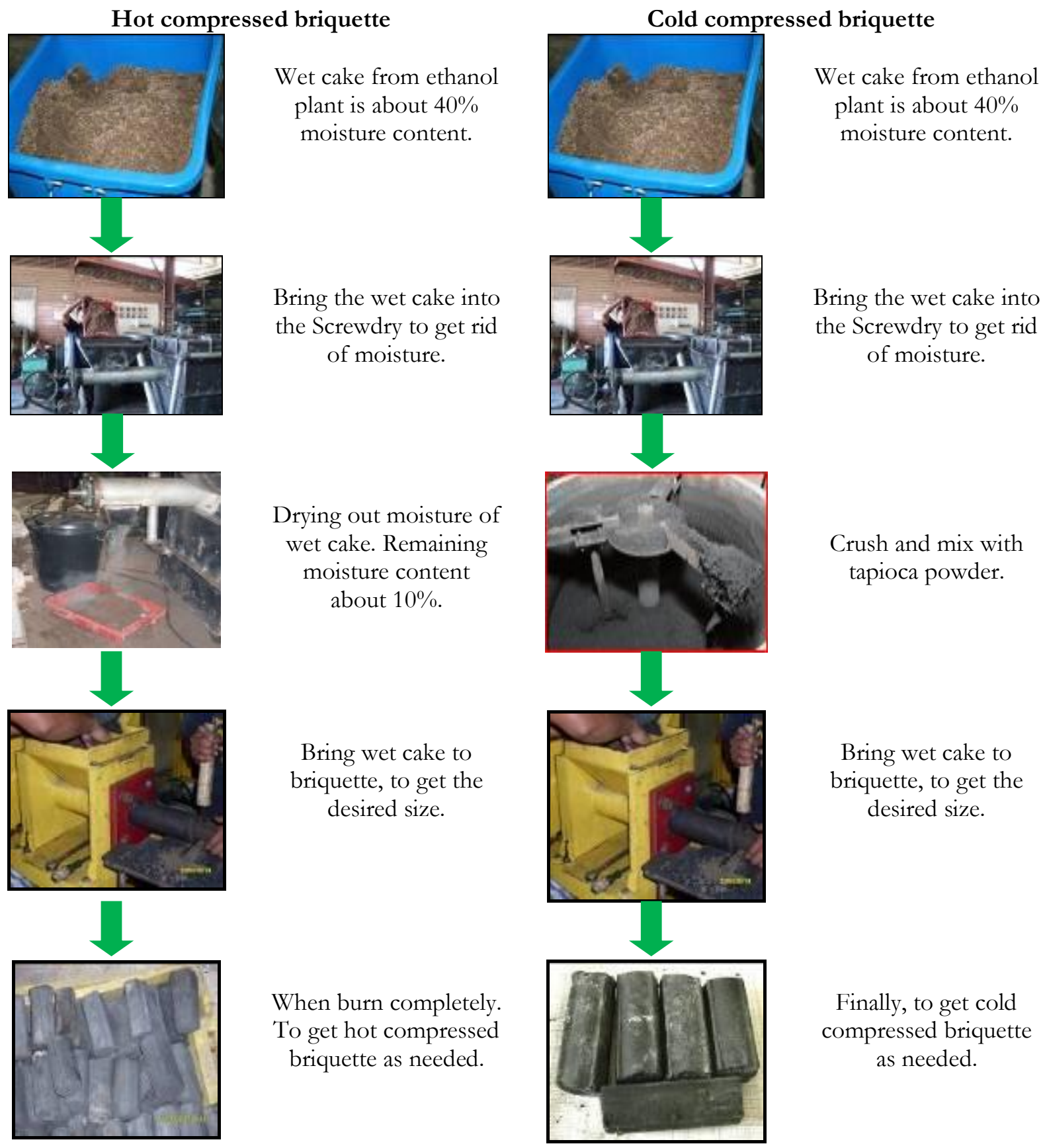

Bring the wet cake into the Screwdry to get rid of moisture.

Drying out moisture of wet cake. Remaining moisture content about $10 \%$.

Bring wet cake to briquette, to get the desired size.

When burn completely. To get hot compressed briquette as needed.

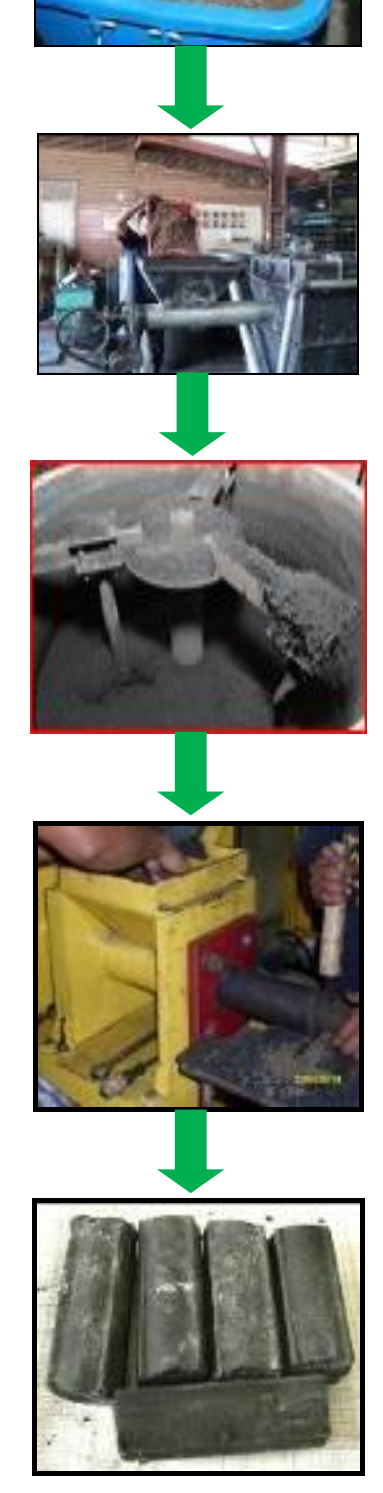

Bring the wet cake into the Screwdry to get rid of moisture.

Crush and mix with tapioca powder.

Bring wet cake to briquette, to get the desired size.

Bring both briquette charcoals to analyze chemical properties, thermal performance and ashes nutrients. Then study economic cost and breakeven point for production in commercial.

\section{Results and Discussion}

\subsection{Characteristics of Wet Cake}

Proximate analysis and heating value are preliminary analysis to investigate the properties of wet cake by ASTM D 3172-3175 and ASTM D 3286 [7-11] as shown in Table 6. 
Table 6. Proximate analysis and heating value of wet cake.

\begin{tabular}{|c|c|}
\hline Components & Percentage by weight \\
\hline Moisture & $7.55 \pm 0.16$ \\
\hline Ash & $15.25 \pm 0.31$ \\
\hline Volatile matter & $63.87 \pm 0.42$ \\
\hline Fixed carbon & $13.33 \pm 0.04$ \\
\hline Heating value & $13,864.38 \mathrm{KJ} / \mathrm{Kg}$ \\
\hline
\end{tabular}

From Table 6, it was found that wet cake is low fixed carbon and heating value only 13.33 percent and $13,864.38 \mathrm{KJ} / \mathrm{Kg}$ respectively. Thus well-suited for improve the wet cake quality prior to use.

\subsection{Optimal Conditions for Carbonization Process}

3.2.1. The effect of temperature and time for the $\%$ yields of wet cake

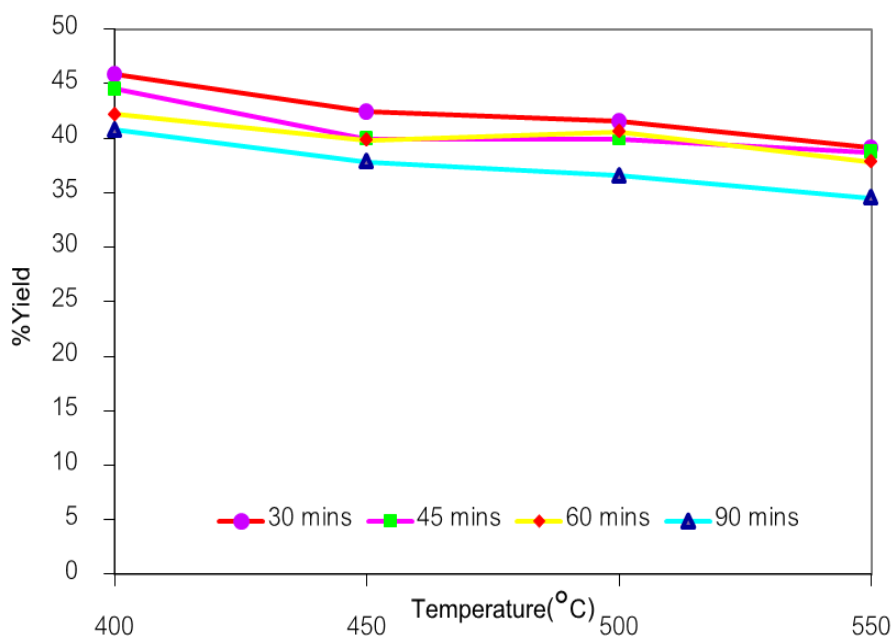

Fig. 4. The effect of temperature and time for the $\%$ yields of wet cake.

Figure 4 shows that when carbonization at higher temperature and longer time. As a result, the $\%$ yields of carbon decreases. Because carbon in wet cake will burn and turn into gas and volatile quickly.

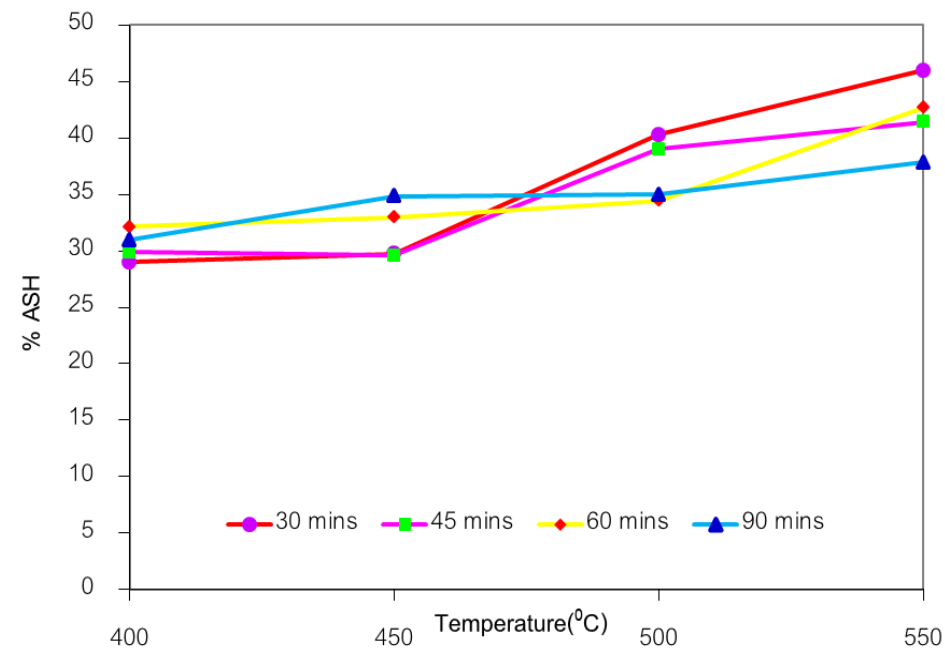

Fig. 5. The effect of temperature and time for the $\%$ ash of wet cake. 
Figure 5 shows that when carbonization at higher temperature at the same time. It is clearly that $\%$ ash of wet cake increased. This can be seen from the carbonization at $400{ }^{\circ} \mathrm{C}$ and $550^{\circ} \mathrm{C} 30 \mathrm{~min}, \%$ ash 29.01 and 45.99 respectively. Because at low temperature, only volatile matter can be eliminated whereas the other components of wet cake still remain. When temperature increases $\%$ ash increases because hydrocarbons will react and change to ashes.

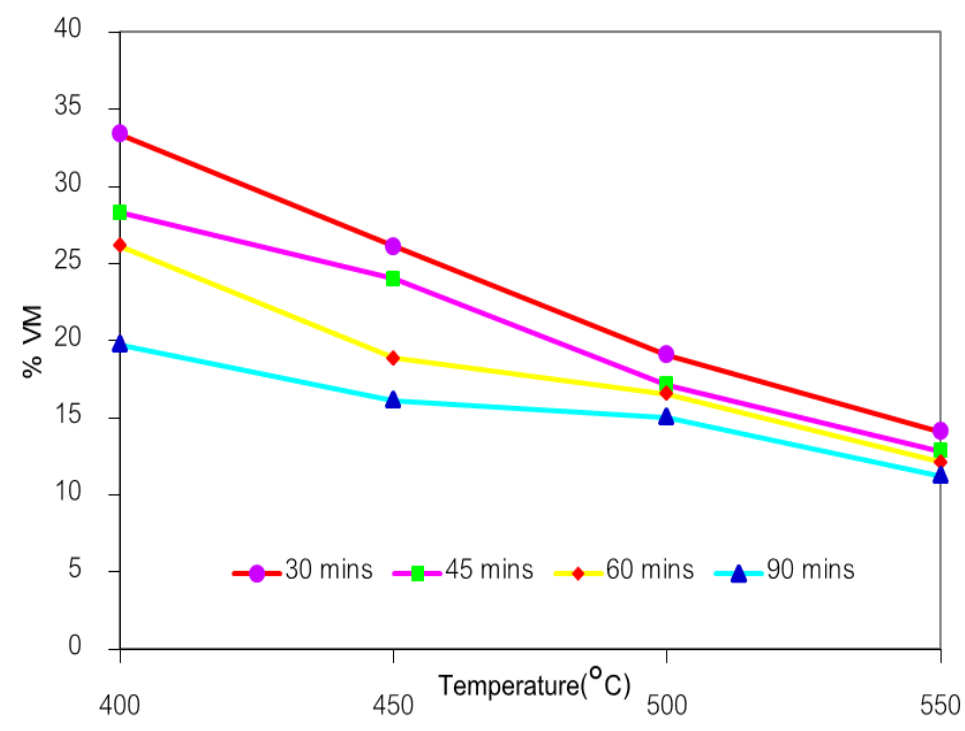

Fig. 6. The effect of temperature and time for the $\%$ volatile matter of wet cake.

Figure 6 shows that $\%$ volatile matter of carbonization in temperature range $400-550^{\circ} \mathrm{C}$ at $30 \mathrm{~min}$ rapidly decreases from $33.41 \%$ to $14.11 \%$. Because at low temperature, only volatile matter can be eliminate as well as carbon in the wet cake will burn as a gas and evaporate in volatile. When temperature rises to $550^{\circ} \mathrm{C} \%$ volatile matter reduces to $14.11 \%$ because some tars and hydrocarbons react and become ashes.

Volatile matter rapidly decreases during $30-60 \mathrm{~min}\left(400-450^{\circ} \mathrm{C}\right)$ because volatile matter on the surface was eliminated. When time more than 60 min volatile matter in wet cake particles will be eliminate but less than volatile matter on surface.

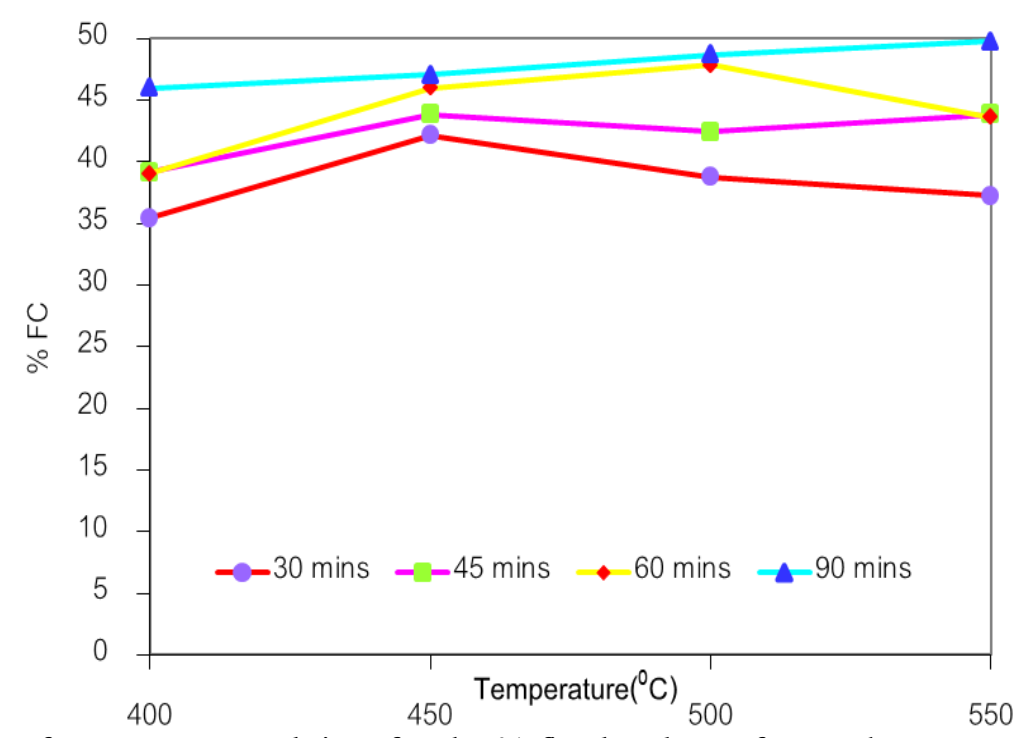

Fig. 7. The effect of temperature and time for the $\%$ fixed carbon of wet cake.

Figure 7 shows that when temperature increases ,\% fixed carbon increases. Because at high temperature will get rid of moisture and volatile constituents as a result \% fixed carbon increases. 
Considering at high temperature resulted in $\%$ yield of wet cake thus must be controlled properly temperature.

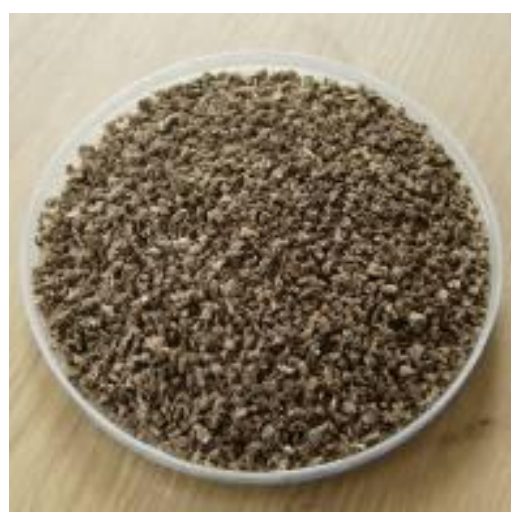

Fig. 8. Wet cake before carbonization.

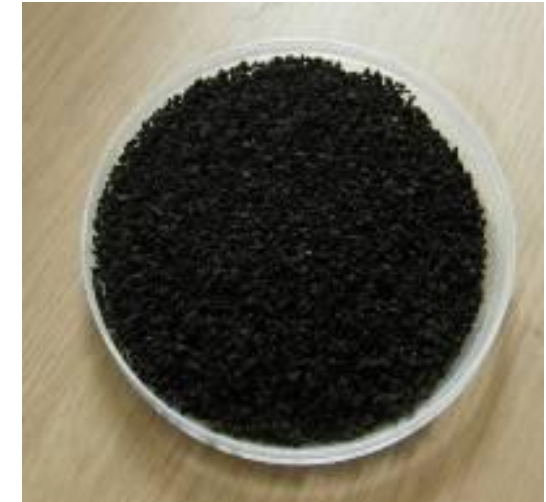

Fig. 9. Wet cake after carbonization.

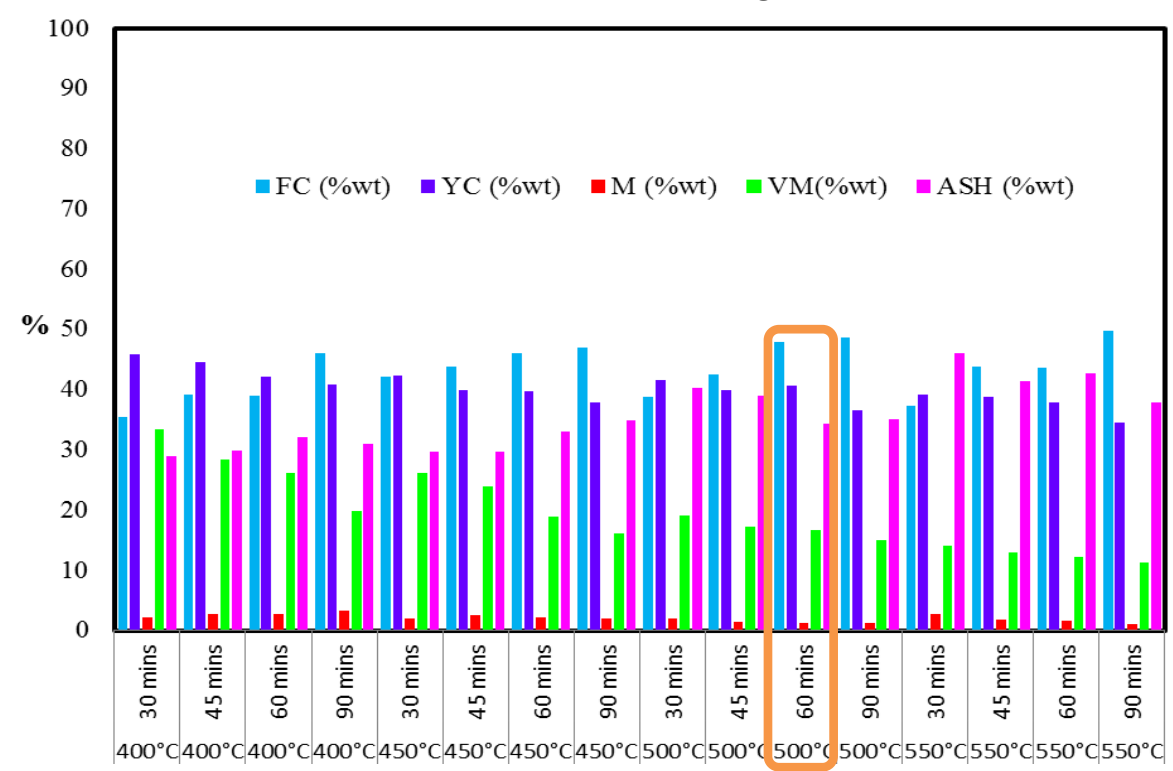

Fig. 10. The results of approximate analysis.

From the above experimental results can be summarized as shown in Fig 10. It was found that the optimal conditions for carbonization is temperature at $500^{\circ} \mathrm{C} 60 \mathrm{~min}, 1.17 \%$ moisture, $16.57 \%$ volatile matter, $34.42 \%$ ash and $47.84 \%$ fixed carbon. When compared to the other temperatures in various ranges such as temperature $400^{\circ} \mathrm{C}$ at different time found that high yields percentage but low fixed carbon. On the other hand when the temperature rises able to get rid of moisture and volatile matter resulted in \% fixed carbon increases. However, carbonization at high temperature would affect on $\%$ yields. Thus the selection of optimal conditions for carbonization should consider both yields and fixed carbon. 


\subsection{Characteristics of Hot and Cold Compressed}

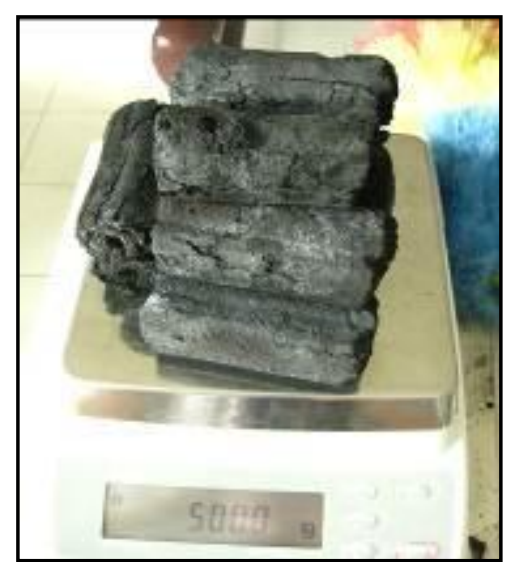

Hot compressed

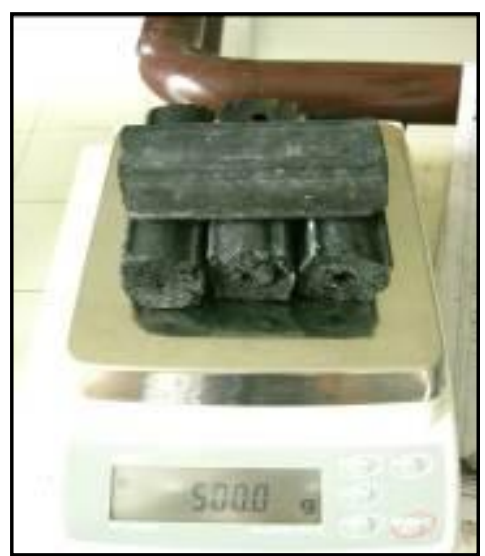

Cold compressed

Table 7. Chemical properties between hot and cold compressed [7-11].

\begin{tabular}{lcc}
\hline Parameter & Hot compressed & Cold compressed \\
\hline moisture & $2.16 \pm 0.03 \%$ & $5.78 \pm 0.07 \%$ \\
ash & $28.98 \pm 0.29 \%$ & $2.41 \pm 0.01 \%$ \\
Volatile matter & $26.20 \pm 0.10 \%$ & $32.80 \pm 0.16 \%$ \\
Fixed carbon & $42.66 \pm 0.36 \%$ & $59.01 \pm 0.08 \%$ \\
Sulfur & $0.110 \%$ & $0.0534 \%$ \\
Heating value & $20,257.25 \mathrm{KJ} / \mathrm{kg}$ & $24,790.21 \mathrm{KJ} / \mathrm{kg}$ \\
\hline
\end{tabular}

Moisture: Cold compressed has moisture more than hot compressed resulted in cold compressed contains water which able to stick particles better.

VOC: Cold compressed has volatile more than hot compressed resulted in cold compressed mixed with tapioca starch. When tapioca starch has been heated, water in the starch will evaporate. Volatile matter on the surface and carbon in wet cake will be burn into gas.

Fixed carbon and heating value: Cold compressed has fixed carbon and heating value more than hot compressed because cold compressed carbonization at high temperature $\left(>500^{\circ} \mathrm{C}\right)$ which fully burn into char resulted in \% fixed carbon has increased.

Ash: Hot compressed has ashes more than cold compressed. Due to low temperature, only volatile matter was removed whereas the other components still remain. When temperature rises, $\%$ ash increases because hydrocarbons in wet cake will react and change to ashes. Cold compressed has ashes less than hot compressed because briquette charcoals consists of char which high fixed carbon.

Sulfur: Cold compressed has sulfur less than hot compressed related to fixed carbon.

\subsection{Performance and Utilization}

Table 8. Summarizes the capabilities of hot compressed and cold compressed.

\begin{tabular}{lcccc}
\hline $\begin{array}{l}\text { Types of briquette } \\
\text { charcoal }\end{array}$ & $\begin{array}{c}\text { Duration of } \\
\text { ignition }\end{array}$ & $\begin{array}{c}\text { Duration of } \\
\text { the heat }\end{array}$ & $\begin{array}{c}\text { Ash } \\
\text { content }\end{array}$ & $\begin{array}{c}\text { Carbon stains } \\
\text { (under the } \\
\text { equipment) }\end{array}$ \\
\hline $\begin{array}{l}\text { Hot compressed } \\
\text { Cold compressed }\end{array}$ & $\sim 5$ minutes & 30 minutes & A lot & medium \\
A minutes & $40-50$ minutes & A little & No \\
\hline
\end{tabular}

Note: Experimental data from real burning. 
Table 9. The nutrient content in the ash from burning briquette charcoal.

\begin{tabular}{lccc}
\hline $\begin{array}{l}\text { Types of briquette } \\
\text { charcoal ash }\end{array}$ & $\begin{array}{c}\text { Nitrogen } \\
(\mathbf{p p m})\end{array}$ & $\begin{array}{c}\text { Nhosphorous } \\
(\mathbf{p p m})\end{array}$ & $\begin{array}{c}\text { Potassium } \\
\text { (ppm) }\end{array}$ \\
\hline $\begin{array}{l}\text { Hot compressed } \\
\text { Cold compressed }\end{array}$ & 10 (Deficiency) & 80 (Surplus) & 80 (Surplus) \\
\hline
\end{tabular}

Note: Experimental data from rapidest 1601 soil test kit accuracy $80 \%$.

Hot compressed: The burning of hot compressed get a little time. A lot of smoke at first. Heat rapidly, moderate carbon stains, a lot of ash, suitable for use as fuel for boiler industry. From the test results of NPK showed that the ashes contain potassium and phosphorus excess $(80 \mathrm{ppm})$ while small amounts of nitrogen $(10 \mathrm{ppm})$. If uses as fertilizers should mixed with composting, manures and rice straw to increase the level of organic matter and soil fertility in long term.

Cold compressed: The burning of cold compressed takes time more than hot compressed. No smoke, evenly thermal, not crackling, no smell, less ashes content and no carbon stains, suitable for use as fuel in grills restaurants. NPK test results showed that potassium and phosphorus excess while small amounts of nitrogen.

\subsection{Preliminary data analysis of costs and economics breakeven for the production of briquette charcoal}

3.5.1. Overview the carbonization of wet cake

: Wet cake $40 \%$ moisture

: Wet cake price $250 \mathrm{baht} / \mathrm{ton}$.

: \% carbonization 33.33

3.5.2. Basic information of the equipment in production

: Screwdry capacity of $100 \mathrm{~kg} /$ hour $\quad 200,000 \mathrm{Baht}$

: Extruder capacity of $100 \mathrm{~kg} /$ hour $\quad 50,000 \mathrm{Baht}$

3.5.3. Basic information the cost of wet cake transporting

: 10-wheeler trucks loaded $15,000 \mathrm{~kg} /$ trip

: The cost of transportation 13,000 baht/trip

: The cost of wet cake transportation $0.86 \mathrm{Baht} / \mathrm{kg}$

3.5.4. Basic information of hot and cold compress

: Hot compressed $0.05 \mathrm{~kg} /$ pieces

: Cold compressed $0.1 \mathrm{~kg} /$ pieces

3.6. The cost analysis and economics breakeven for the production of hot and cold compressed

Table 10. Details of production costs of hot and cold compressed.

\begin{tabular}{|c|c|c|}
\hline Details & Hot compressed & Cold compressed \\
\hline Fixed cost $(\mathrm{F})$ & $250,000 \mathrm{Baht}$ & $250,000 \mathrm{Baht}$ \\
\hline Raw materials cost & $0.03125 \mathrm{Baht} /$ piece & $0.0625 \mathrm{Baht} /$ piece \\
\hline Transportation cost & 0.1100 Baht/piece & $0.2175 \mathrm{Baht} / \mathrm{piece}$ \\
\hline Labor cost & $0.0100 \mathrm{Baht} /$ piece & $0.0215 \mathrm{Baht} /$ piece \\
\hline Electricity cost & $0.0150 \mathrm{Baht} /$ piece & $0.0100 \mathrm{Baht} / \mathrm{piece}$ \\
\hline Water cost & - & $0.0010 \mathrm{Baht} / \mathrm{piece}$ \\
\hline Tapioca cost & - & $0.0050 \mathrm{Baht} / \mathrm{piece}$ \\
\hline Production cost & $0.1700 \mathrm{Baht} /$ piece & $0.3175 \mathrm{Baht} / \mathrm{piece}$ \\
\hline
\end{tabular}


From Table 10. production cost of hot and cold compressed calculated from cost of raw materials, transportation, labor, electricity, water and tapioca is $0.17 \mathrm{baht} /$ piece. Assuming sale price of coal 10.5 $\mathrm{baht} / \mathrm{kgs}$, thus prices of hot and cold compressed $0.525 \mathrm{baht} /$ piece and $1.05 \mathrm{baht} /$ piece respectively.

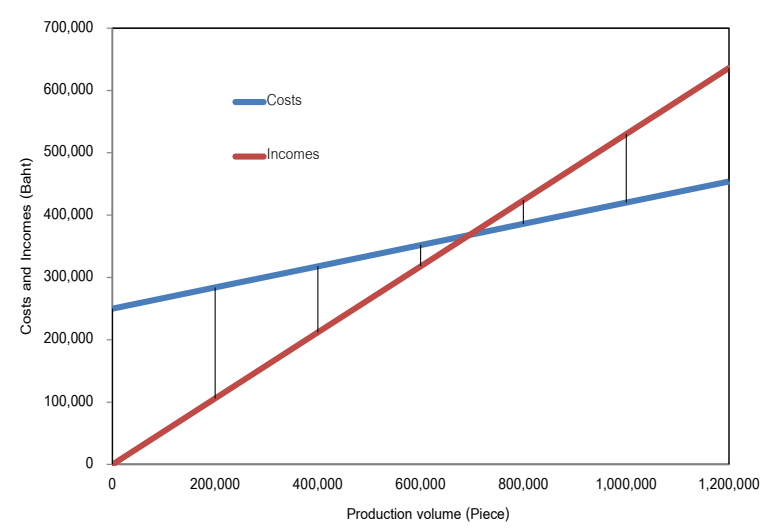

Fig. 11. The number of breakeven points in the production of hot compressed

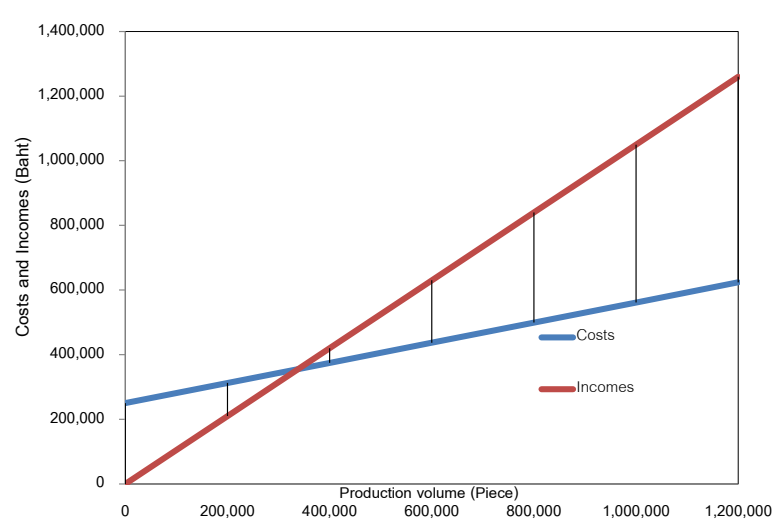

Fig. 12. The number of breakeven points in the production of cold compressed

From Fig.11. and 12 the breakeven point of hot and cold compressed calculated from fixed cost $(\mathrm{F})$ divided by price cost (P) minus variable cost (V), thus breakeven point of hot and cold compressed 704,225 and 341,297 pieces respectively. Payback period at breakeven point calculated from pieces at breakeven point $\left(\mathrm{N}^{*}\right)$ divided by number of pieces/year $(\mathrm{N})$. Payback period of hot and cold compressed 0.18 and 0.17 years respectively.

\section{Conclusions}

The improvement of physical property of wet cake waste from ethanol industry by carbonization into char was right approach because at high temperature will get rid of moisture and volatile matter as a result $\%$ fixed carbon and heating value increases. The application of wet cake waste to produce hot and cold compressed for utilization in various forms found that both briquette charcoals were high thermal efficiency and environmental friendly. Moreover economics cost of both briquette charcoals are very low compare to the other biomass. In the near future, briquette charcoals from wet cake waste are an interesting alternative fuel.

\section{References}

[1] Department of Alternative Energy Development and Efficiency. (2008). Operators are permitted construction of ethanol plant to use as fuel. [Online]. Available: http://www.dede.go.th

[2] Department of Alternative Energy Development and Efficiency. (2006). Final report the utilization of waste from ethanol production to add value. [Online]. Available http://www.dede.go.th

[3] M. J. Antal, Jr., K. Mochidzuki, and L. S. Parades, "Flash carbonization of biomass," Ind. Eng. Chem., vol. 42, pp. 3690-3699, 2003.

[4] K. Raksanit and K. Saeungduan, "Carbonization of biomass for effective utilization," B.S. thesis, Chemical Technology, Chulalongkorn Univ., Bangkok, Thailand, 2006.

[5] S. R. Teixeira,, A. F. V. Pena, and A. G. Miguel, "Briquetting of charcoal from sugar-cane bagasse fly ash (scbfa) as an alternative fuel," Waste management, vol. 30, no. 5, pp. 804-807, May 2010.

[6] P. Fu, W. Yi, X. Bai, Z. Li, S. Hu, and J. Xiang, "Effect of temperature on gas composition and char structural features of pyrolyzed agricultural residues," Bioresource Technology, vol. 102, pp. 8211-8219, 2011.

[7] American Standard of Testing Material, "Standard practice for proximate analysis of coal and coke," in Annual Book of ASTM Standard D 3172-89, 1993, pp. 288.

[8] American Standard of Testing Material, "Standard test method for moisture in the analysis sample of coal and coke," in Annual Book of ASTM Standard D 3173-87, 1993, pp. 289-290. 
[9] American Standard of Testing Material, "Standard test method for ash in the analysis sample of coal and coke," in Annual Book of ASTM Standard D 3174-93, 1993, pp. 291-294.

[10] American Standard of Testing Material, "Standard test method for volatile matter in the analysis sample of coal and coke," in Annual Book of ASTM Standard D 3175-89a (Reapproved 1993), 1993, pp. 295-297.

[11] American Standard of Testing Material, "Standard test method for gross calorific value in the analysis sample of coal and coke by the isoperibol bomb calorimeter," in Annual Book of ASTM Standard D 3286-96, 1998. 
